\title{
Have Patagonian waterfowl been affected by the introduction of the American mink Mustela vison?
}

\author{
Salvador J. Peris, Javier Sanguinetti and Moisés Pescador
}

\begin{abstract}
The American mink Mustela vison has spread widely beyond its native North American range and is associated with problems for the conservation of native species because of its impact as both predator and competitor. We investigated the impact of feral mink on waterfowl in Lanín National Park, south-west Neuquén, Patagonia, Argentina, an area in which the predator is currently expanding. Statistically significant differences were observed in the number of waterfowl species at lakes without mink (7.3 \pm SE 0.7) compared to those with mink (4.0 \pm SE 0.6). Overall abundance of birds observed per day was higher at lakes without (104.2 \pm SE 20.6) than with mink (21.2 \pm SE 22.3). The great grebe Podiceps major, speckled teal Anas flavirostris, Chiloe wigeon Anas sibilatrix and red-gartered coot Fulica armillata were more abundant on water bodies without mink, and flocks of the ashy-headed goose Chloephaga poliocephala were larger in areas without mink. Other species, such as the white-tufted grebe Rollandia rolland, coscoroba swan Coscoroba coscoroba, black-necked swan Cygnus melanocoryphus, cinnamon teal Anas cyanoptera, Andean duck Oxyura jamaicensis and Andean gull Larus serranus were never observed in areas harbouring mink. We conclude that at least 12 of the 25 waterfowl species observed are sensitive to the presence of the mink, either being absent or having a lower abundance where mink are present.
\end{abstract}

Keywords Argentina, mink, Mustela vison, Patagonia, population impact, waterfowl abundance

\section{Introduction}

A fter habitat loss, invasive species are the second greatest threat to biodiversity (Hulme, 2003). Diagnosis of their impact on native species is therefore a fundamental problem in conservation biology (Park, 2004). One such invasive species is the American mink Mustela vison, a predator introduced extensively into Europe, Asia and southern areas of South America (Macdonald \& Strachan, 1999; MacDonald et al., 2007). In Argentina mink farms were started in the 1950 s in the southern province of

\footnotetext{
Salvador J. Peris (Corresponding author) and Moisés Pescador Departamento de Zoología, Facultad de Biología, Universidad de Salamanca, 37071 Salamanca, Spain. E-mail peris@usal.es

Javier SANGuinetTi Sección Técnica del Parque Nacional Lanín, San Martín de los Andes, Parques Nacionales de Argentina, Neuquen, Argentina.

Received 15 April 2008. Revision requested 16 June 2008.

Accepted 2 October 2008.
}

Chubut. There have been successive escapes, either accidental or through the abandonment of nurseries (Pagnoni et al., 1986), and the species has increased its range to the north and east, following the numerous river-beds and lakes of the Andean mountain range.

In North America, the original source of mink, the predator is responsible for $65-68 \%$ of predation on eggs and nestlings of waterfowl (Pietz et al., 2003; Krapu et al., 2004). In Europe the impact of the expansion of mink on native bird life is appreciable and has been documented in Central Europe and Scandinavia (Andersson, 1992; Craik, 1997; Nordström et al., 2002; Bartoszewicz \& Zalewski, 2003; Bonesi \& Palazon, 2007), Great Britain (Macdonald \& Harrington, 2003) and the Mediterranean region (Bonesi \& Palazon, 2007). In South America excreta sampling (Medina, 1997; Previtali et al., 1998) of the summer diet of mink shows that it consumes crustaceans, mollusc bivalves, and small mammals and birds but little is known, probably because of the sampling methods used, of any differential consumption of bird species.

The aim of the work reported here was to explore the possible effect of the recent presence and progressive expansion of mink on the waterfowl population during the reproductive season, the time of year when any such impact may be most significant (Brzezinski \& Marzec, 2003), in the water bodies of an extensive area in Patagonia.

\section{Study area}

The study was carried out in the c. 412,013 ha Lanín National Park, created in 1937 in south-west Neuquén, Argentina, with Chile to the west and the Nahuel Huapi National Park at its southernmost tip (Fig. 1). The Park lies between the Andes and the Patagonian steppe. It preserves landscapes of the Andean-Patagonian forests, with tree species such as the pehuén or araucaria Araucaria araucaria, northern beech and oak-beech (Nothofagus spp.) and Austral cypress Austrocedrus chilensis.

The Park includes mountain ranges whose altitude falls towards the east, blending into a smoothly undulating topography with a large number of glacial lakes and short heavy-flowing rivers. The heads of nine of the rivers are located on the eastern side of the Andes and belong to the Negro river basin; another river belongs to the western Andean side, together with a series of locked basins known as arreicas and other closed lagoons. The Park is subdivided into a northern sector, with the basins of the Lakes Norquinco, Rucachoroi and Quillén, a northern central 


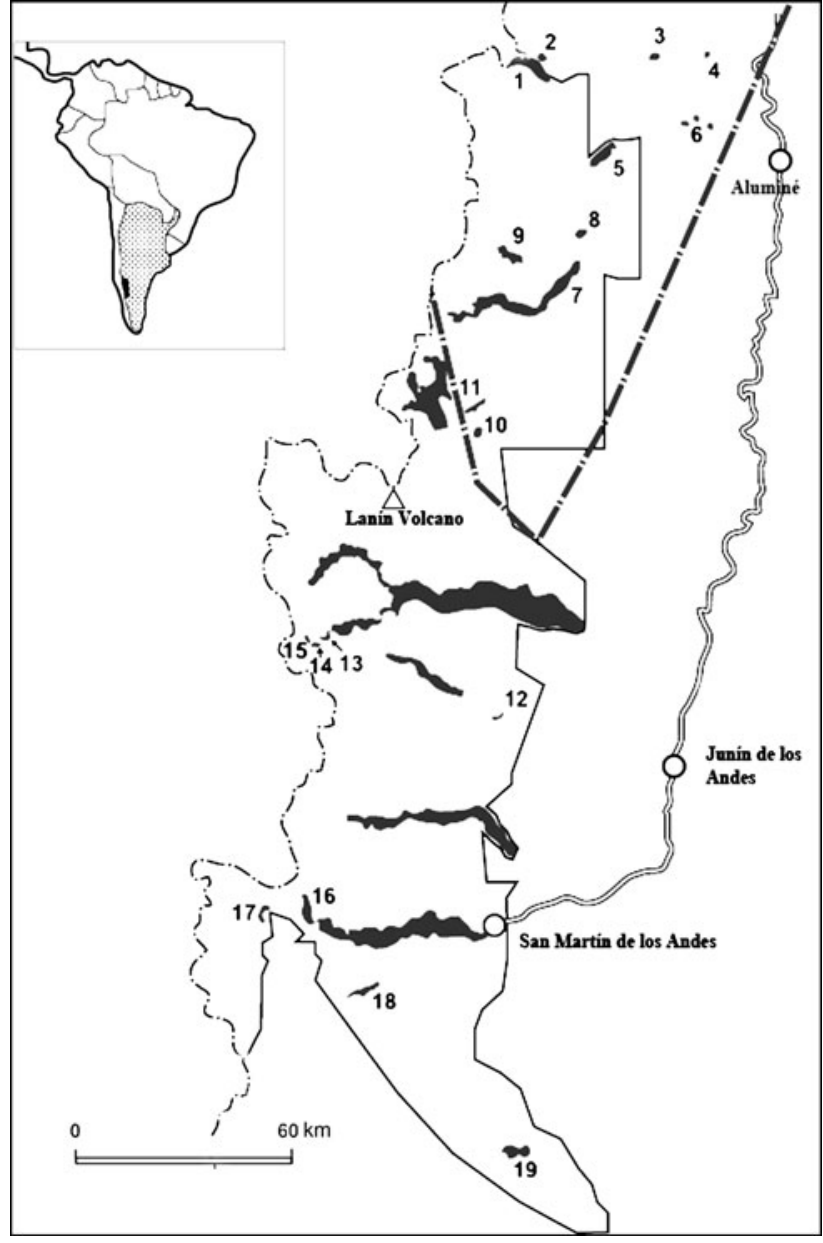

Fig. 1 Lanín National Park in Patagonia, Argentina. Numbers indicate the 21 water bodies surveyed (see Table 2 for names). The dashed line marks the northern limit of mink Mustela vison in 2007.

sector, including the basins of the Lakes Tromen, Huechulafquen and Curruhué, and a southern central sector that includes Lácar Lake, which flows to the Pacific Ocean, and Lolog Lake. The southern sector encompasses the basins of the Lakes Meliquina-Hermoso and Filo Hua-Hum, bordering the southern Nahuel Huapi National Park.

All the lakes are deep (e.g. the Quillén has a maximum depth of $155 \mathrm{~m}$ ), and the water is moderately acidic in water bodies $>50$ ha ( $\mathrm{pH}$ 6.1-5.5); lagoons $<25$ ha are alkaline, with a pH of 7.9-9.0 (S.J. Peris, J.Sanguinetti \& M. Pescador, unpubl. data). Mean rainfall is $>1,500 \mathrm{~mm}_{\text {year }}{ }^{-1}$, with a maximum of $2,800 \mathrm{~mm}_{\text {year }}{ }^{-1}$ in the north central sector. The region has a low human density (1.84 inhabitants $\mathrm{km}^{-2}$; Iglesias \& Pérez, 1998).

\section{Methods}

Mink were first detected in Lanín National Park in 1994, although it was not until 1996-1997 that the species was commonly observed. Since then, it has colonized seven of the 12 river basins of the Park, occupying c. $208 \mathrm{~km}$ of lake edges and $900 \mathrm{~km}$ of the rivers and streams that flow into the Atlantic, i.e. an advance of $19-82 \mathrm{~km}_{\text {year }}{ }^{-1}$ (Funes et al., 2006). Since 1996 another invasion from Chile has been detected, affecting Lake Lácar. To detect mink, systematic sampling was carried out based on indications of the activity of the species (tracks, excreta, direct observations and occasional captures with traps) recorded by park rangers during 1996-2005. The method comprised 1,000-m transects that followed the edges of the lakes, ponds and main river-beds of the National Park.

The proportion of waterfowl in the diet of mink is related to waterfowl density, and is particularly high during the breeding season (Medina, 1997; Previtali et al., 1998). During 10-19 November 2005 (pre-reproductive season) and 16-23 January 2006 (post-reproductive season), in a total of 18 days of fieldwork, censuses of all waterfowl species (Podicipediformes, Ciconiiformes, Anseriformes, Gruiformes and Charadriiformes) were made at 21 lakes and lagoons that had a maximum area of 661 ha. The surface limit was adopted to allow us to survey all the birds at each site, something impossible to achieve at larger lakes (e.g. the 12,000 ha Huechulafquen). On each visit all species of birds were identified and, as far as possible, an exact count was made using optical devices of $8 \times 40$ to $20 \times 60$. Surveys were conducted by teams of 2-6 (mostly four) trained observers.

At each wetland 20-60 minutes were spent counting birds, depending on area, covering the whole perimeter with line transects along the bank or point counts. All censuses were on foot. Counts were not made on days or at times with strong wind, which creates swelling, or at times when poor light hindered observation. The data recorded included physical and botanical descriptions of each water body.

As surface area influences species composition and the abundance of waterbirds (Uresk \& Severson, 1988; Guadagnin et al., 2005), the lakes and lagoons sampled were grouped in four size categories: (1) small, which included six ponds of 2-10 ha; (2) medium, which included six lakes of $42-78 \mathrm{ha}$; (3) large, which included five lakes of $296-347$ ha; (4) very large, which included four lakes of 407-661 ha.

Differences in waterfowl populations between sites with respect to the presence or absence of mink were tested using $\chi^{2}$ tests. Once checks of normality and homoscedasticity had been made, total bird abundances were analysed using one-way analysis of variance (Sokal \& Rohlf, 1994). A logistic regression (Lewis, 2004) was used to examine the relative effects of waterfowl species, survey dates and category of water body on the presence of mink. Statistical analyses were performed using SPSS $v$ 15.o (SPSS, Chicago, USA).

\section{Results}

A total of 27 species of waterfowl were observed at the 21 water bodies. Abundance of waterfowl and area of water 
TABLE 1 Variables selected, and not selected, by logistic regression as predictors of the presence/absence of mink Mustela vison.

\begin{tabular}{|c|c|c|c|c|c|}
\hline Variable & $\beta$ & SE & $\begin{array}{l}\text { Wald's } \\
\text { statistic }\end{array}$ & $\mathrm{df}$ & $\mathrm{P}$ \\
\hline \multicolumn{6}{|c|}{ Variables in the regression } \\
\hline $\begin{array}{l}\text { Waterfowl } \\
\text { abundance }\end{array}$ & 0.694 & 0.167 & 17.225 & 1 & $<0.001$ \\
\hline Lake size & -0.456 & 0.150 & 9.193 & 1 & 0.002 \\
\hline Constant & -1.201 & 0.269 & 19.953 & 1 & $<0.001$ \\
\hline \multicolumn{6}{|c|}{ Variables not in the regression } \\
\hline Survey dates & 0.001 & 0.000 & 3.361 & 1 & 0.067 \\
\hline
\end{tabular}

bodies were significant predictors in a logistic regression model of the presence/absence of mink (Table 1). On water bodies with a surface area of $<200$ ha we observed a mean of 6-7 waterfowl species per day compared to 5-6 species on larger bodies, although the difference was not significantly different $\left(F_{3,35}=0.23, \mathrm{P}>0.05\right)$. The total number of waterfowl observed per day was, however, significantly different between water bodies $\left(F_{3,35}=1.11, \mathrm{P}>0.05\right.$; Table 2$)$. There was a tendency towards a greater abundance of birds (mean 87.4-96.2 day $^{-1}$ ) on lakes $<100$ ha than on larger lakes (28.3-53.5 day ${ }^{-1}$; Fig. 2).

The mean number of species observed per day per water body was $6.3 \pm$ SE 0.77 in November and $5.83 \pm$ SE 0.84 in January but the difference between the two periods was not statistically significant $\left(F_{1,37}=0.192, \mathrm{P}>0.05\right)$. Similarly, the mean number of individuals observed per day per water body in November (64.5 \pm SE 16$)$ and January $(81.5 \pm$ SE 25.2) were not significantly different $\left(F_{1,37}=0.34, \mathrm{P}>0.05\right)$.

There was a significant difference $\left(F_{1,37}=10.1, \mathrm{P}=0.003\right)$ in the number of waterfowl species observed per day on water bodies without mink ( $7.3 \pm \mathrm{SE} 0.7)$ compared to those with mink (4.0 \pm SE 0.6). Similarly, the mean number of individuals observed per day on water bodies without mink was significantly higher (104.2 \pm SE 20.6) than with mink (21.2 \pm SE 22.3; $F_{1,37}=9.7, \mathrm{P}=0.004$; Fig. 2).

Ten waterfowl species were not observed on water bodies containing mink and four species were significantly more common on lakes without than with mink (Table 3): great grebe Podiceps major $\left(\chi^{2}=6,528, \mathrm{P}=0.013\right)$, speckled teal Anas flavirostris $\left(\chi^{2}=7.769, \mathrm{P}=0.006\right)$, Chiloe wigeon Anas sibilatrix $\left(\chi^{2}=6.310, \mathrm{P}=0.012\right)$ and red-gartered coot Fulica armillata $\left(\chi^{2}=3.365, \mathrm{P}=0.046\right)$. The ashy-headed goose Chloephaga poliocephala had mean flock sizes of $37.0 \pm$ SE 11.48 and $3.38 \pm$ SE 0.80 in areas without and with mink, respectively, and the difference was statistically significant $\left(F_{1,19}=5.16, \mathrm{P}=0.03\right)$.

\section{Discussion}

Of a total of 27 waterfowl species observed on water bodies where mink were absent only 17 were observed at water bodies where mink were present. In addition, there were significantly more individuals of four species on water bodies with

TABLE 2 Mean numbers of species and individuals per day (with SE) observed at each of the 21 water bodies surveyed (Fig. 1). Note that three water bodies close together are jointly labelled 6 .

\begin{tabular}{lrcc}
\hline Water body & Surface (ha) & No. of species \pm SE & No. of individuals \pm SE \\
\hline 1, Norquinco & 661 & $7.50 \pm 0.71$ & $45.50 \pm 31.82$ \\
2, Nompehuen & 81 & $8.00 \pm 2.83$ & $52.50 \pm 43.13$ \\
3, Pulmari & 178 & $13.00 \pm 1.41$ & $273.00 \pm 19.41$ \\
4, Los Giles & 10 & $8.50 \pm 0.71$ & $292.00 \pm 53.76$ \\
5, Rucachoroi & 347 & $13.00 \pm 0$ & $152.00 \pm 31.75$ \\
6, Nanco & 2 & $9.00 \pm 0$ & $106.00 \pm 40.51$ \\
6, Segunda laguna & 2 & $4.50 \pm 1.50$ & $45.00 \pm 23.84$ \\
6, Diaheu & 2 & $8.50 \pm 0.50$ & $126.00 \pm 19.57$ \\
7, Quillén & 49 & $6.00 \pm 0$ & $155.00 \pm 32.58$ \\
8, Coipu & 24 & $7.00 \pm 0$ & $64.00 \pm 0$ \\
9, Hui-Hui & 307 & $2.00 \pm 1.41$ & $5.00 \pm 4.24$ \\
10, Laguna Chica & 3 & $4.50 \pm 0.71$ & $30.00 \pm 8.48$ \\
11, Huaca Mamuil & 22 & $3.50 \pm 0.71$ & $14.50 \pm 6.36$ \\
12, Curruhue Chico & 42 & $6.50 \pm 2.12$ & $61.00 \pm 14.14$ \\
13, Carilafquen & 106 & $1.00 \pm 1.00$ & $1.00 \pm 1.00$ \\
14, El Escorial & 11 & $2.50 \pm 0.50$ & $10.00 \pm 5.66$ \\
15, Laguna Verde & 47 & $3.50 \pm 0.71$ & $16.50 \pm 2.51$ \\
16, Nonthue & 468 & $6.00 \pm 1.41$ & $15.50 \pm 10.60$ \\
17, Queñi & 412 & $2.50 \pm 0.71$ & $8.00 \pm 4.24$ \\
18, Lago Escondido & 296 & $1.50 \pm 0.71$ & $3.50 \pm 3.53$ \\
19, Filo Hua-Hum & 407 & $7.50 \pm 2.12$ & $44.50 \pm 16.50$ \\
\hline
\end{tabular}

${ }^{\star}$ Only for the north-eastern arm (total lake area is c. 2,400 ha) 

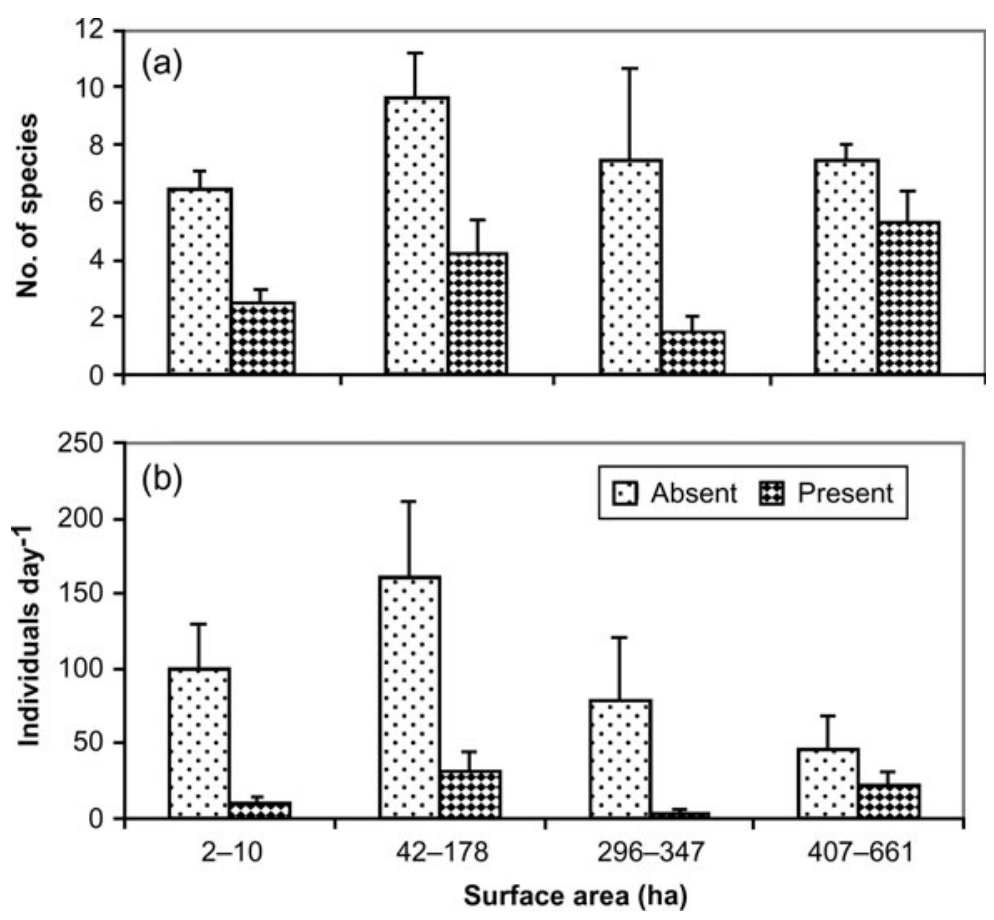

FIG. 2 (a) Mean number of species of waterfowl and (b) mean total number of waterfowl observed per day in water bodies (Fig. 1, Table 2) of four categories of surface area according to whether mink were present or absent. Vertical bars represent the standard error. mink compared to water bodies without mink, and a greater overall abundance of waterfowl on mink-free water bodies.

For 13 of the waterfowl species observed the data are insufficient to allow us to test whether presence/absence or abundance of individuals has a relationship with the presence of mink. Nevertheless the relationship between the presence of mink and some waterfowl species was clear. The ashy-headed goose, for example, was present as only 1-2 pairs at some water bodies, such as Filo Hua-Hum, where mink have been present for 12 years. At the beginning of the 1990 s they were counted there in groups of hundreds (data from Domingo and Jinny Taylor, owner of the Estancia Tres Lagos).

According to excreta analyses carried out in the UK, coots Gallinula chloropus and ducks (Anas spp.) comprise $15.3-16.4 \%$ and $2-4 \%$, respectively, of the mink's diet (Macdonald \& Strachan, 1999). However, in other areas of Europe, such as Poland, predation of mink on birds in spring and summer comprises $45-60 \%$ of breeding birds. Ducks (Anas spp.) and the European coot Fulica atra were the species most predated (11.2 and $7.8 \%$, respectively), followed by grebes (Podiceps spp.; 1.8\%). Only $13.6 \%$ of the nests of common geese Anser anser are successful in areas with mink (Nordström et al., 2002). In Chile birds comprise only 2.6\% of mink diet (Medina, 1997), whereas in Argentina they form a higher proportion (30\%; Previtali et al., 1998).

There is a debate about whether or not the presence of mink has decreased waterfowl populations (Brzezinski \& Marzec, 2003; Bartoszewicz \& Zaleswski, 2003), although in Finland the mink has limited the populations of small ducks (Nordström et al., 2002) and gulls (Banks et al., 2008). Adult birds of small and medium size could be more suitable prey for mink than larger species, probably because the latter are more successful at protecting their nest and young (Nordström \& Korpimäki, 2004). Waterbird colonies may be effective at protecting themselves against diurnal predators but not against mainly nocturnal predators such as mink (Banks et al., 2008). Bird colonies are easier to locate, and attract predators. The ashy-headed goose, a colonial-breeding species, is one of the species most affected by mink in Patagonia (Schüttler et al., 2009).

In general, high predation by mink on aquatic birds can be explained by the relative abundance of birds in comparison to the availability of crustaceans, small mammals and fish (Chanin \& Linn, 1980). In our study area, rivers such as Limay and Hua Hum are rich in crustaceans but other water bodies lack this prey and, although no data on crustaceans are available for the water bodies we surveyed, the diet of mink in nearby areas is most diverse in those basins with crustaceans (Fasola et al., 2009). In Sweden and North America, in habitats similar to those in Patagonia, the proportion of waterbirds in the mink's diet may increase to $78 \%$, especially coots $(70 \%)$, during the birds' breeding season (Gerell, 1967; Eberhardt \& Sargeant, 1977). We do not know whether there is similarly high predation on coots in Patagonia, where Fulica spp. are able to produce up to two clutches per year, which could made them less sensitive to mink predation. In contrast, the two geese species, nesting at the edges of water bodies and in fields close to lakes, may be easy prey for mink, and as they have only one clutch per year they may be more sensitive to such predation. The lack of significant differences in abundance of some bird species between areas with and without mink could be because of lower predation by mink in the central zones of Lanín 
TABLE 3 Mean numbers (with SE) of 27 species of waterfowl observed per day at water bodies (Fig. 1, Table 1) with and without mink.

\begin{tabular}{|c|c|c|}
\hline Species & Mean no. without mink $( \pm$ SE) & Mean no. with mink $( \pm$ SE) \\
\hline White-tufted grebe Rollandia rolland & $1.80 \pm 0.37$ & \\
\hline Pied-billed grebe Podilymbus podiceps & $1.00 \pm 0$ & $1.00 \pm 0$ \\
\hline Great grebe Podiceps major & $2.83 \pm 1.04$ & $2.20 \pm 0.39$ \\
\hline Neotropic cormorant Phalacrocorax olivaceus & $3.17 \pm 0.87$ & $7.00 \pm 4.24$ \\
\hline Great white egret Egretta alba & $1.00 \pm 0$ & \\
\hline Cocoi heron Ardea cocoi & $1.00 \pm 0$ & \\
\hline White-faced ibis Plegadis chihi & $1.00 \pm 0$ & \\
\hline Black-faced ibis Theristicus melanopis & $6.33 \pm 2.55$ & $4.00 \pm 1.00$ \\
\hline Chilean flamingo Phoenicopterus chilensis & $2.00 \pm 1.00$ & \\
\hline Coscoroba swan Coscoroba coscoroba & $2.67 \pm 0.66$ & \\
\hline Black-necked swan Cygnus melanocoryphus & $15.67 \pm 7.69$ & \\
\hline Upland goose Chloephaga picta & $12.75 \pm 7.61$ & $2.00 \pm 1.00$ \\
\hline Ashy-headed goose Chloephaga poliocephala & $37.00 \pm 11.48$ & $3.38 \pm 0.80$ \\
\hline Flying steamer duck Tachyeres patachonicus & $7.00 \pm 2.53$ & $1.67 \pm 0.33$ \\
\hline Spectacled duck Anas specularis & $2.00 \pm 0$ & $2.00 \pm 0$ \\
\hline Yellow-billed pintail Anas georgica & $7.13 \pm 3.32$ & $12.00 \pm 7.00$ \\
\hline Speckled teal Anas flavirostris & $16.78 \pm 5.20$ & $7.00 \pm 1.41$ \\
\hline Chiloe wigeon Anas sibilatrix & $11.18 \pm 3.98$ & $3.00 \pm 2.30$ \\
\hline Cinnamon teal Anas cyanoptera & $2.00 \pm 1.00$ & \\
\hline Red shoveler Anas platalea & $10.20 \pm 4.64$ & $2.00 \pm 1.00$ \\
\hline Andean duck Oxyura jamaicensis & $5.18 \pm 1.46$ & \\
\hline Plumbeous rail Pardirallus sanguinolentus & $30.00 \pm 25.00$ & $1.00 \pm 1.00$ \\
\hline Red-gartered coot Fulica armillata & $40.14 \pm 13.86$ & $13.75 \pm 5.40$ \\
\hline White-winged coot Fulica leucoptera & $16.38 \pm 6.89$ & $11.17 \pm 5.59$ \\
\hline Southern lapwing Vanellus chilensis & $4.29 \pm 0.95$ & $2.50 \pm 0.34$ \\
\hline Kelp gull Larus dominicanus & $3.20 \pm 1.24$ & $1.33 \pm 0.33$ \\
\hline Andean gull Larus serranus & $5.75 \pm 1.84$ & \\
\hline
\end{tabular}

National Park, where the abundance of the introduced European rabbit Oryctolagus cuniculus, another important mink prey, could reduce predation pressure on waterbirds.

Information on mink diet in Patagonia, with sporadic observations of its predation on waterbirds, is provided in Medina (1997) and Previtali et al. (1998). A mink was captured after hunting a Magellanic penguin Spheniscus magellanicus on the Guerrico seaboard (Tierra del Fuego). In the same region mink destroyed nests of Magellan geese Chloephaga picta (Rozzi \& Sherriffs, 2003). Mink can birds nesting at lakes and ponds in a different way to birds nesting in rivers. Predation on nests of Canadian geese Branta canadensis and mallards Anas platyrhynchos has been reported to be $<48 \%$ on remote islands temporarily isolated from predators when strong river flows limit the arrival of predators, although mink is the predator least affected by such increases in river volume (Zoellick et al., 2004).

Birds choose nest sites where the risk of predation is smallest (Martin, 1993) and some waterfowl may be able to adapt to a new predator. In Europe the common moorhen Gallinula chloropus, which normally nests on the ground, builds nests in trees in areas where mink have been present for 15-20 years (Ferreras \& Macdonald, 2001). In cases where nests are lost to predation other species, such as the coot, build a second nest in $47 \%$ of cases, and even a third (11\%) in areas with mink (Macdonald \& Strachan, 1999). It is possible that Patagonian species of Fulica may do the same. Our personal observations of Chloephaga indicate a preliminary anti-predator behaviour: in areas where mink have been present for 10-12 years the geese locate their nests away from lake edges.

An important finding of our study is that at least 12 of the total of 27 waterfowl species that we observed in Lanín National Park appear to be sensitive to the presence of mink, reflected either by their absence or lower numbers on water bodies where mink are present. Future issues that need to be researched are the relationship of the abundance of mink with that of waterbirds, and possible existence of anti-predator behaviour by birds such as has been observed in those European areas where the mink has been established from a long time.

The Patagonian landscape, with its richness of rivers and lakes draining to the Pacific coast of Chile and Atlantic coast of Argentina has some legal protection, with a number of national parks and other protected areas. However, this is a favourable habitat for mink, with mink farms in both countries. Although the relevant authorities are aware of the situation, effective anti-mink control is not yet available, at least not in Argentina. It is therefore likely that the range of 
mink will continue to increase in northern Patagonia, with concomitant effects on waterfowl.

\section{Acknowledgements}

Financial support came from the Spanish MEC project CGL2004-01716-Feder. We wish to thank the park rangers Pedro Prieto (Aluminé), Juan Jones (Ñorquinco), Sebastián Ravicule and Mónica Guzmán (Lanín), Sebastián Farchola and Bianca Napolitano (Curruhué) and Silvia Vergara (Queñi and Filo Hua-Hum) for logistical aid, for their time spent with us and their local knowledge. We greatly appreciate the collaboration of the volunteers and workers of Global Vision International for collaboration with the fieldwork, especially Tom, Shandy, Sharon and Gaspar.

\section{References}

Andersson, A. (1992) Development of waterbird populations in the Bullerö archipelago of Stockholm after colonization by mink. Ornis Svecica, 2, 107-118.

Banks, P.B., Nordström, M., Ahola, M., Salo, P., Fey, K. \& KORPIMÄкI, E. (2008) Impacts of alien mink predation on island vertebrate communities of the Baltic Sea archipelago: review of a long-term experimental study. Boreal Environment Research, $13,3-16$.

Bartoszewicz, M. \& Zalewski, A. (2003) American mink, Mustela vison, diet and predation on waterfowl in the Slonsk Reserve, western Poland. Folia Zoologica, 5, 225-238.

Bonesi, L. \& Palazon, S. (2007) The American mink in Europe: status, impacts, and control. Biological Conservation, 134, 470-483.

BrZeZinski, M. \& MARZec, M. (2003) The origin, dispersal and distribution of the American mink Mustela vison in Poland. Acta Theriologica, 48, 505-514.

Chanin, P.R.F. \& Linn, I. (1980) The diet of the feral mink (Mustela vison) in southwest Britain. Journal of Zoology, 192, 205-223.

CraIK, J.C. (1997) Long-term effects of North American mink Mustela vison on seabirds in western Scotland. Bird Study, 44, 303-309.

Eberhardt, L.E. \& Sargeant, A.B. (1977) Mink predation on prairie marshes during the waterfowl breeding season. In Proceedings of the 1975 Predator Symposium (eds R.L. Phillips \& C. Jonkel), pp. 33-43. Montana Forest Conservation Experiment Station, University of Montana, Missoula, USA.

Fasola, L., Chehébar, C., Macdonald, D.W., Porro, G. \& Cassini, M.H. (2009) Do alien North American mink compete for resources with native South American river otter in Argentinean Patagonia? Journal of Zoology, 277, 187-195.

Ferreras, P. \& Macdonald, D.W. (2001) The impact of American mink Mustela vison on water birds in the upper Thames. Journal of Applied Ecology, 36, 701-708.

Funes, M.C., Sanguinetti, J., LaClau, P., Maresca, L., Garcia, L., Mazzieri, F. et al. (2006) Diagnóstico del estado de conservación de la biodiversidad del Parque Nacional Lanín, su viabilidad de protección en el largo plazo. Informe inédito. Parque Nacional Lanín, San Martín de los Andes, Neuquén, Argentina.

Gerell, R. (1967) Food selection in relation to habitat in mink (Mustela vison Schreber) in Sweden. Oikos, 18, 233-246.

Guadagnin, D.L., Schmitz-Peter, A., Carvalho, L.F. \& Mattchik, L. (2005) Spatial and temporal patterns of waterbird assemblages in fragmented wetlands of southern Brazil. Journal of the Waterbird Society, 28, 261-272.

Hulme, P.E. (2003) Biological invasions: winning the science battles but losing the conservation war? Oryx, 37, 178-193.

Iglesias, C.G. \& Pérez, A.A. (1998) Patagonia. In Los Humedales de la Argentina. Clasificación, situación actual, conservación y legislación. Publ. no. 46 (eds P. Canevari, D.E. Blanco, E. Bucher, G. Castro \& I. Davidson), pp. 115-135. Wetlands International 46, Secretaria de Recursos Naturales y Desarrollo Sustentable, Buenos Aires, Argentina.

Krapu, G.L., Pietz, P.J., Brandt, D.A. \& Cox, R.R. (2004) Does presence of permanent fresh water affect recruitment in prairienesting dabbling ducks? Journal of Wildlife Management, 60, 332-341.

LEwis, K.P. (2004) How important is the statistical approach for analysing categorical data? A critique using artificial nests. Oikos, 104, 305-315.

Macdonald, D.W. \& Harrington, L.A. (2003) The American mink: the triumph and tragedy of adaptation out of context. New Zealand Journal of Zoology, 30, 421-441.

Macdonald, D.W. \& STRAChan, R. (1999) The Mink and the Water Vole. Analyses for Conservation. Environment Agency/ Wildlife Conservation Research, Oxford, UK.

MacDonald, R.A., O'Hara, K. \& Morrish, D.J. (2007) Decline of invasive alien mink (Mustela vison) is concurrent with recovery of native otters (Lutra lutra). Diversity and Distributions, 13, 92-98.

Martin, T.E. (1993) Nest predation and nest sites: new perspectives on old patterns. BioScience, 43, 523-532.

Medina, G. (1997) A comparison of the diet and distribution of southern river otter (Lutra provocax) and mink (Mustela vison) in southern Chile. Journal of Zoology, 242, 291-297.

Nordström, M., Högmander, J., Nummelin, J., Laine, J., LaAnetu, N. \& Korpimäкi, E. (2002) Variable responses of waterfowl breeding populations to long-term removal of introduced American mink. Ecography, 25, 385-394.

Nordström, M. \& KorPIMÄKI, E. (2004) Effects of island isolation and feral mink removal on bird communities on small islands in the Baltic Sea. Journal of Animal Ecology, 73, 424-433.

Pagnoni, G.O., Garrido, J. \& Marín, M.R. (1986) Impacto económico y ambiental del visón, Mustela vison (Schreber, 1877) en el norte de la Patagonia. CENPAT-CONICET, Dirección de Fauna Silvestre, Provincia de Chubut, Argentina.

PARK, K. (2004) Assessment and management of invasive alien predators. Ecology and Society, 9, 204-220.

Pietz, P.J., Krapu, G.L., BRAndt, D.A. \& Cox, R.R. (2003) Factors affecting gadwall brood and duckling survival in prairie pothole landscapes. Journal of Wildlife Management, 67, 564-575.

Previtali, A., Cassini, M. \& Macdonald, D.W. (1998) Habitat use and diet of the American mink (Mustela vison) in Argentinian Patagonia. Journal of Zoology, 246, 482-486.

RozZi, R. \& SHERrifFs, M. (2003) El visón (Mustela vison Schreber, Carnivora: Mustelidae), un nuevo mamífero exótico para la isla Navarino. Anales Instituto Patagonia, 31, 97-104.

Schüttler, E., Klenke, R., McGehee, S., Rozzi, R. \& Kurt Jax, K. (2009) Vulnerability of ground-nesting waterbirds to predation by invasive American mink in the Cape Horn Biosphere Reserve, Chile. Biological Conservation, 142, 1450-1460.

Sokal, R. \& Rohlf, F. (1994) Biometry. The Principles and Practice of Statistics in Biological Research. W.H. Freeman, New York, USA.

URESK, D.W. \& SEVERSON, K. (1988) Waterfowl and shorebird use of surface-mined and livestock water impoundments on the northern Great Plains. Great Basin Naturalist, 48, 353-357. 
Zoellick, B.W., Ulmschneider, H.M., Cade, B.S. \& Stanley, A.W. (2004) Isolation of snake river islands and mammalian predation of waterfowl nests. Journal of Wildlife Management, $68,650-662$.

\section{Biographical sketches}

SALVADOR J. PERIS's research focuses on the relationships between abundances of birds and mammals and human impact, including the influence of land-use changes and man-made infrastructures on animal diversity. He is currently studying introduced species in South America, the impact of wind farms on birds and bats in Central America, and the ecology of mountain bird species in Spain. JAVIER SANGUINETTI is carrying out research on production of acorns by Araucaria araucaria and its relationship with its mammalian predators. Moisés PESCADOR is working on the impact of past and present land use and agricultural practices on bird communities. His interests encompass not only cultivated areas but also other environments functioning as habitats for bird species. 